\title{
The performance of agronomic traits, genetic variability, and correlation studies for yield and its components in some red rice (Oryza sativa) promising lines
}

\author{
GUSTI RAY SADIMANTARA ${ }^{1}$, DEWI NURHAYATI YUSUF ${ }^{2, \bullet}$, EKA FEBRIANTI ${ }^{1}$, SITTI LEOMO ${ }^{2}$, \\ MUHIDIN $^{1}$ \\ ${ }^{1}$ Department of Agrotechnology, Faculty of Agriculture, Universitas Halu Oleo. Jl. HEA Mokodompit, Kendari 93212, Southeast Sulawesi, Indonesia \\ ${ }^{2}$ Department of Soil Sciences, Faculty of Agriculture, Universitas Halu Oleo. Jl. HEA Mokodompit, Kendari 93212, Southeast Sulawesi, Indonesia. \\ vemail: dewi.yusuf@uho.ac.id
}

Manuscript received: 15 April 2021. Revision accepted: 28 August 2021.

\begin{abstract}
Sadimantara GR, Yusuf DN, Febrianti E, Leomo S, Muhidin. 2021. The performance of agronomic traits, genetic variability, and correlation studies for yield and its components in some red rice (Oryza sativa) promising lines. Biodiversitas 22: $3994-4001$. Improving a new variety commonly depends on the nature and magnitude of genetic variability and its utilization, followed by selection and evaluation before being released into new superior types. The present study aims to estimate the genetic variability and relation between yield and its related traits of the red rice promising lines. The experiment was arranged based on a randomized complete block design (RCBD) with three replications. Analysis of variance revealed significant differences among rice lines for 12 quantitative traits. The phenotypic coefficient of variation (PCV) value was higher than the genotypic coefficient of variation (GCV), indicating a negligible environmental influence in the phenotypic expression of traits. High heritability estimates coupled with high genetic advance were recorded for grain total per panicle and grain yield per hill. Grain yield observed a highly significant positive correlation with panicle length (0.63), percentage of filled grains (0.53), grain weight per panicle (0.54), and thousand-grain weight $(0.52)$. It correlated negatively with days to $50 \%$ flowering $(-0.61)$ and days to maturity $(-0.48)$. The study indicated that panicle length, percentage of filled grains, grain weight per panicle, and thousand-grain weight are important yield-related traits and could be used for selection to improve the genetic potential of rice yield.
\end{abstract}

Keywords: Correlation, genetic variability, paddy field, promising lines, red rice, yield-related characters

\section{INTRODUCTION}

Rice is a staple food and still the primary source of carbohydrate intake (Priyanka and Jaiswal 2017). It consumes $90 \%$ in Asia and mainly in Southeast Asia, including Indonesia (Manzanilla et al. 2011; Panuju et al. 2013). The rice demand in Indonesia continues to increase with population growth, while the rice production capacity to increase is minimal (Sutariati et al. 2017; Muhidin et al. 2018). The population increased, and the wetland conversion, causes rice supply cannot be fulfilled sustainably (Muhidin et al. 2013; Sutariati et al. 2016; Kadidaa et al. 2017).

Besides being a source of carbohydrates, rice also contains proteins, fats, fiber, minerals, and anthocyanins (Sivamaruthi et al. 2018; Thanuja and Parimalavalli 2018), mainly for red rice. Red rice is a functional food with a high health value (Ravichanthiran et al. 2018). Anthocyanin is a phenolic compound that is included in the flavonoid group and functions as an antioxidant (Goufo and Trindade, 2014). Thus, it plays an essential role for the plant itself and human health.

Rice demand is expected to rise in the future as the world's population grows. Rice self-sufficiency has been the subject of numerous efforts (Sutariati et al. 2017; Kadidaa et al. 2017). Several programs have been created to increase rice production in Indonesia, including increasing productivity (Sutariati et al. 2018), breeding program (Suliartini et al. 2018; Sadimantara et al. 2019), and also trying to decrease rice level consumption and promote local food as a carbohydrate source (Muhidin et al. 2016). One of the promises programs to achieve this target is upland rice development to increase rice production (Kadidaa et al. 2017; Sadimantara et al. 2018) planted on dry land (Sutariati et al. 2018). Common problems in upland rice cultivation are mostly because of low-level production and length of harvest time. One of the solutions is through the breeding program to increase upland rice production and shorten harvest time. The productivity of rice plants can be increased through the development of superior varieties in plant breeding programs.

Rice breeding is critical for food production to meet the needs of a growing population (Osei et al. 2014; Lenaerts et al. 2018). To date, improved rice varieties must be developed to increase rice production to meet rising demand (Osei et al. 2014).

In the country where rice consumption has increased, the high-yielding cultivar with broad adaptation capabilities to diverse environments needs to be developed (Hyoda et al. 2015; Bailey-Serres et al. 2019; Takai et al. 2019). According to Akter et al. (2014), the development of improved varieties can increase the productivity of red rice 
through plant breeding programs. Several upland rice lines have assembled through crossbreeding between superior lowland rice and local upland rice cultivars. Via crossbreeding between local upland rice and paddy rice cultivars, Sadimantara et al. (2014) have assembled many promising red rice lines. Furthermore, these red rice crossbreed lines must be evaluated in the rice field to determine the potential yield and adaptability. The crossing-derived lines have been tested on dry land through yield ability and multilocation tests.

A character's appearance within a population is determined by genetic variation, environment, genetic and environmental interactions (Griffiths et al. 2005). The selection of parents solely based on the yield is often deceptive. As a result, understanding the relationship between yield and its related traits is needed for plant breeders to develop an economically viable variety (Khan et al. 2015; Li et al. 2019; Qaim 2020). Genetic diversity for the agronomic trait is a vital component of breeding programs to expand rice and other crops' gene pool (da Silva Dias 2015; Xu et al. 2017; Bailey-Serres et al. 2019). When combined with the heritability calculation, the genetic coefficient of variation would provide the best reference for the amount of advance predicted from the selection (Kumar et al. 2017). Plant selection can be aided by correlation studies between yield and its contributing characters (Pratap et al. 2020). The correlation coefficient may also be used to distinguish characters with little or no effect on rice yield.

Any crop improvement program's success is determined by genetic variability, heritability, genetic advance, character interaction, direct and indirect effects on yield, and its attributes, all of which are influenced by the genotypes' genetic diversity (Rashmi et al. 2017; Adhikari et al. 2018; Saha et al. 2019). The evaluation and analysis of genetic diversity are critical for crop enhancement and the efficient management and conservation of germplasm resources (Govindaraj et al. 2015; Yan et al. 2016; Bhandari et al. 2017). The breeding program to increase the economic value of rice focused on breeding for high yield and pest resistance and introducing favored quality characteristics (Khan et al. 2015; Kaiser et al. 2020). The study aimed to quantify the diversity indices, variability, and heritability of various traits to aid effective selection in a rice breeding program.

\section{MATERIALS AND METHODS}

\section{Experimental materials and design}

The research was conducted at the Extended Experimental Garden, Department of Agrotechnology, Faculty of Agriculture, Halu Oleo University Kendari Southeast Sulawesi Indonesia, during the growing season in 2019 from July to November 2019. The experimental material in this study comprised eight new upland rice lines derived from Inpari-33 x Wagamba crosses, and the name of the cultivar are GS11-1, GS11-2, GS12-1, GS12-2, GS44-1, GS44-2, GS16-1, GS16-2, developed from the cross between paddy rice and local upland rice, and one local upland rice as a check variety.

The red rice promising lines were planted in a randomized complete block design with three replications. Twenty-eight days old seedlings were transplanted in the experimental site with a spacing of $25 \mathrm{~cm}$ between plant to plant and 25 between the rows, keeping a single seedling per hill. The standard agronomic practices had applied for average plant growth. Five plants were randomly chosen from each replication in each line for yield-related traits. Twelve traits were observed, i.e., plant height, leaf area, flag leaf angle, flag leaf area, panicle length, filled grain percentage, grain total per panicle, grain weight per panicle, thousand-grain weight, days to $50 \%$ flowering, days to maturity, and grain yield per hill. The observations were recorded and subjected to statistical analysis using the mean values of five randomly selected plants.

\section{Statistical analysis}

The analysis of variance was done using SPSS 23.0 software. Parameters of genetic variability include mean, range, genotypic and phenotypic coefficient of variation were calculated according to the method suggested by Burton (1952), and the estimate of GCV and PCV were classified as low (0-10\%), moderate (10-20\%) and high (20\% and above) according to Sivasubramanian and Madhavamenon (1973). The broad-sense heritability and genetic advance in percent of mean were calculated as suggested by Jonson et al. (1955). Normal Pearson's correlation was calculated using SPSS 20.0 software. The Heritability estimates were categorized as low (0-30\%), moderate (30-60\%), and high (60\% and above) as given by Robinson et al. (1949). Genetic advance as percent of mean was categorized as low (0-10\%), moderate (10-20\%), and high (20\% and above) as given by Johnson et al. (1955) and Falconer (1996). The value of genetic and phenotypic diversity is derived from analysis of variance, such as presented in Table 1.

Based on variance analysis, phenotype and genotype variations can be predicted as follows:

$$
\begin{aligned}
& \sigma_{g}^{2}=\frac{M 2-M 1}{r} \\
& \sigma_{e}^{2}=M 1 \\
& \sigma_{p}^{2}=\sigma_{g}^{2}+\sigma_{e}^{2}
\end{aligned}
$$

Where:

$\sigma_{g}^{2}=$ Genotype Variance,

$$
\sigma_{p}^{2}=\text { Phenotype Variance }
$$

Table 1. Analysis of variance and genetic parameters

\begin{tabular}{lccc}
\hline \multicolumn{1}{c}{ SV } & DF & MS & E (MS) \\
\hline Block & $(\mathrm{r}-1)$ & M3 & $\sigma_{e}^{2}+g \sigma_{r}^{2}$ \\
Genotype & $(\mathrm{g}-1)$ & M2 & $\sigma_{e}^{2}+r \sigma_{g}^{2}$ \\
Error (a) & $(\mathrm{r}-1)(\mathrm{g}-1)$ & M1 & $\sigma_{e}^{2}$
\end{tabular}

Total $\mathrm{rg}-1$

Note: SV: source of variation; DF: Degree of Freedom, MS Mean Square; EMS: Expected Mean Square; r: block; g: genotype 
Genotypic coefficient of variation (GCV) and phenotypic coefficient of variation (PCV) are calculated according to the formula:

$$
K K F=\frac{\sqrt{\sigma_{p}^{2}}}{\bar{Y}} \times 100 \% \quad K K G=\frac{\sqrt{\sigma_{g}^{2}}}{\bar{Y}} \times 100 \%
$$

Where:

$\bar{Y} \quad$ : population mean

GCV: Genotypic Coefficient of Variation

PCV : Phenotypic Coefficient of Variation

\section{RESULTS AND DISCUSSION}

\section{Field performance}

The results of the phenotypic study of eight promising rice lines showed in Table 2 . There is a large variability among observed genotypes, which can be used for further breeding programs. The DMRT was carried out to determine the differences between genotypes in all characters. The findings revealed that among the promising rice lines, except for the filled grain percentage, almost all yield-related attributes of red rice promising lines were higher than the check variety based on phenotypic results.

The highest value for plant height, leaf area, and flag leaf angle was observed in GS16-2, and the lowest value for plant height was exhibited in GS12-2, for leaf area and flag leaf angle in GS44-2. The highest Flag leaf area was observed in GS16-1, and the lowest value was exhibited in GS11-1. The generative character found that the highest value for panicle length was observed in GS16-1 while the lowest value was exhibited GS11-2. The highest filled grain percentage was found in GS12-2 and the lowest found in GS44-2. The highest grain total panicle ${ }^{-1}$ was found in GS12-1, and the lowest was found in GS11-2. The highest grain weight panicle ${ }^{-1}$ was found in GS16-1, and the lowest was found in GS11-1. The GS44-1 lines were recorded as the highest weight of 1000 grains and days to $50 \%$ flowering. The lowest thousand-grain weight and the fastest day to 50\% flowering found in GS12-1.
The longest day to maturity was 104.00 days found in GS12-1, GS12-2, GS44-1and GS44-2. The shortest day to maturity was 100.00 days found in GS11-1, GS11-2, GS16-1 and GS16-2. Furthermore, the GS16-1 recorded as red rice promising lines with the highest grain yield, which was statistically different from other varieties, and the lowest was in GS11-1.

\section{Genetic variability}

The degree of variability for a given trait is required to improve the breeding of field crops. The estimates of genotypic variation $(\sigma 2 \mathrm{~g})$, phenotypic variation $(\sigma 2 \mathrm{p})$, genotypic coefficient of variation $(\mathrm{GCV})$, phenotypic coefficient of variation (PCV), heritability $(\mathrm{h} 2 \mathrm{~b})$, genetic advance (GA), and genetic advance as percentage of the mean (GAM) for different characters have been presented in Table 3.

The genetic analysis revealed significant substantial variations among all the promising lines for all the traits examined. The PCV and GCV values of the characters analyzed in this study were low, moderate, and strong. Days to $50 \%$ flowering had the highest PCV and GCV values among the yield characters, followed by grain total per panicle and grain weight per panicle.

The parameter of days to $50 \%$ flowering (53.82) had the highest genotypic coefficient of variation (GCV), followed by grain total per panicle (33.85), grain weight per panicle (26.26), flag leaf area (22.58), and leaf area (21.52), suggesting a higher degree of genetic heterogeneity among the red rice lines tested for these traits. Ansari et al. (2010) found similar findings with different hybrid rice maintainer lines. The GCV and PCV values (Table 2) were recorded high for leaf area, flag leaf area, grain total per panicle, grain weight per panicle, and days to $50 \%$ flowering. This result was in agreement with the finding reported by Shrivastava et al. (2015), Gautam et al. (2016), Devi et al. (2017), Srujana et al. (2017), and Choudhary et al. (2018)

Table 2. Mean performance of eight red rice promising lines and a check variety

\begin{tabular}{|c|c|c|c|c|c|c|c|c|c|}
\hline \multirow[t]{2}{*}{ Traits } & \multicolumn{8}{|c|}{ Rice promising lines } & \multirow{2}{*}{$\begin{array}{l}\text { Check } \\
\text { variety }\end{array}$} \\
\hline & GS11-1 & GS11-2 & GS12-1 & GS12-2 & GS44-1 & GS44-2 & GS16-1 & GS16-2 & \\
\hline $\mathrm{PH}$ & $43.83 b$ & $44.20 \mathrm{~b}$ & 50.56a & $44.23 b$ & $44.43 b$ & $47.11 b$ & $46.05 b$ & $51.17 \mathrm{a}$ & $39.98 \mathrm{c}$ \\
\hline LA & $12.76 \mathrm{ab}$ & $12.14 \mathrm{ab}$ & $14.71 \mathrm{a}$ & $11.38 \mathrm{ab}$ & $12.01 \mathrm{ab}$ & $11.27 \mathrm{ab}$ & $12.40 \mathrm{ab}$ & $15.11 \mathrm{a}$ & $10.46 \mathrm{~b}$ \\
\hline FLA & $12.42 \mathrm{ab}$ & $12.11 \mathrm{ab}$ & $12.64 \mathrm{a}$ & $12.09 \mathrm{ab}$ & $11.93 \mathrm{ab}$ & $11.57 \mathrm{ab}$ & $12.84 \mathrm{ab}$ & $12.97 \mathrm{a}$ & $10.24 b$ \\
\hline FLW & $21.48 \mathrm{c}$ & $20.98 \mathrm{c}$ & $25.66 \mathrm{~b}$ & $23.37 b c$ & $21.68 \mathrm{c}$ & $25.53 b$ & $30.85 a$ & $27.78 \mathrm{a}$ & $22.64 b c$ \\
\hline PL & $23.83 b$ & $23.53 b$ & $25.27 \mathrm{a}$ & $24.17 \mathrm{ab}$ & $24.83 \mathrm{ab}$ & $25.10 \mathrm{a}$ & $25.60 \mathrm{a}$ & $23.93 b$ & $20.37 \mathrm{c}$ \\
\hline $\mathrm{FG} / \mathrm{P}$ & $76.02 b c$ & $73.54 b c$ & $79.06 \mathrm{ab}$ & $79.32 \mathrm{ab}$ & $76.34 b c$ & $68.49 \mathrm{c}$ & $74.26 \mathrm{bc}$ & $77.19 b c$ & $86.93 a$ \\
\hline GT/P & $128.18 b$ & $126.53 b$ & $166.69 \mathrm{a}$ & $144.75 \mathrm{ab}$ & $141.17 \mathrm{ab}$ & $146.64 \mathrm{ab}$ & $163.91 \mathrm{a}$ & $145.29 \mathrm{ab}$ & $75.08 \mathrm{c}$ \\
\hline GW/P & $2.53 \mathrm{~b}$ & $2.60 \mathrm{ab}$ & $2.80 \mathrm{ab}$ & $2.83 \mathrm{ab}$ & $2.93 \mathrm{a}$ & $2.60 \mathrm{ab}$ & $2.95 \mathrm{a}$ & $2.77 \mathrm{ab}$ & $1.73 \mathrm{c}$ \\
\hline TGW & $28.55 \mathrm{ab}$ & $26.92 b$ & $26.05 b$ & $26.77 \mathrm{~b}$ & $30.74 a$ & $28.58 \mathrm{ab}$ & 29.92ab & $28.16 a b$ & $26.50 \mathrm{~b}$ \\
\hline DTF & 69.00ab & $69.67 \mathrm{a}$ & $67.67 \mathrm{~b}$ & $70.57 \mathrm{a}$ & $70.67 \mathrm{a}$ & $70.00 \mathrm{a}$ & 69.00ab & 69.33ab & $54.00 \mathrm{c}$ \\
\hline DTM & $100.00 \mathrm{~b}$ & $100.00 \mathrm{~b}$ & $104.00 \mathrm{a}$ & $104.00 \mathrm{a}$ & $104.00 \mathrm{a}$ & $104.00 \mathrm{a}$ & $100.00 \mathrm{~b}$ & $100.00 \mathrm{~b}$ & $84.00 \mathrm{c}$ \\
\hline GY & $26.63 c$ & $28.62 b$ & $26.88 b c$ & $28.16 \mathrm{~b}$ & $27.51 b c$ & $29.51 b$ & $35.88 \mathrm{a}$ & $29.20 \mathrm{~b}$ & $34.94 \mathrm{a}$ \\
\hline
\end{tabular}

Note: Means followed by the same letter in the same row are not significantly different. PH: Plant height, LA: Leaf area, FLA: Flag leaf angle, FLW: Flag leaf area, PL: Panicle length, FG/P: Filled grain percentage, GT/P: Grain total per panicle, GW/P: Grain weight per panicle, TGW: Thousand-grain weight, DTF: Days to 50\% flowering, DTM: Days to maturity, GY: Grain yield per hill. 
Moderate estimates of phenotypic and genotypic coefficients of variation were recorded for panicle length, filled grain percentage, days to maturity, and grain yield per hill. In the present study, moderate GCV and PCV were obtained for plant height, flag leaf angle, panicle length, filled grain percentage, days to maturity, and grain yield per hill; this was in agreement with Choudhary et al. (2018) and partial agreement with Devi et al. (2017). Thousandgrain weight showed low GCV and PCV (<10\%), which was in accord with Hossain et al. (2016), and Sohgaura et al. (2014). The lowest PCV and GCV values were recorded thousand-grain weight parameter.

According to the analysis of variability parameters, the phenotypic coefficient of variation (PCV) was higher than the genotypic coefficient of variation (GCP) for all of the characters analyzed in this research, which could be due to the environment's role in the phenotypic expression of the characteristics to some extent. This conformed with earlier (Ravishanker et al. 2013; Akter et al. 2020). The limited variations in genotypic and phenotypic coefficients of variance suggested that environmental factors had little effect on the speech of these characters. These findings are consistent with those reported previously (Adhikari et al. 2018; Tiwari et al. 2019).

Heritability and genetic advance are essential parameters in the selection of rice traits. The genetic advance helps quantify the amount of improvement that might be expected with selection in a character, while heritability measures the relative amount of the heritable portion of variance (Bello et al. 2012; Khan et al. 2016; Keerthana et al. 2019). Genetic advance is a valuable measure of the progress that can be expected from selecting the relevant population (Reddy et al. 2013; Islam et al. 2015; Ajmera et al. 2017; Terfa and Gurmu 2020). Heritability combined with genetic advance would provide a more accurate index of selection value (Senapati et al. 2013; Oladosu et al. 2014; Huda et al. 2018).

Heritability estimates in a broad sense $\left(\mathrm{h}^{2}{ }_{\mathrm{bs}}\right)$ were recorded high for all the traits evaluated. High heritability estimates help make the selection of superior genotypes based on phenotypic performance. The estimates of heritability and genetic advance as percent of mean were high for plant height, leaf area, flag leaf angle, flag leaf area, panicle length, filled grain percentage, grain total per panicle, grain weight per panicle, thousand-grain weight, and yield per hill. It indicates the predominance of additive gene action, and hence the direct selection is useful for these traits. In general, the characters that recorded high heritability with high genetic advances are controlled by additive gene action and can be improved through simple or progeny selection methods (Sravan et al. 2014; Roy and Shil 2020).

High heritability combined with moderate genetic advance as percent of mean was recorded only for days to maturity. High heritability combined with low genetic advance as percent of mean was recorded for days to $50 \%$ flowering parameter. For selecting the best individual, heritability estimates and genetic gain would be more useful (Singh et al. 2011). Similar results were also recorded by Adhikari et al. (2018) on lowland irrigated rice. Broad-sense heritability helps estimate the inheritance of a character by explaining both fixable (additive) and non-fixable (dominant and epistatic) variances (Nirmaladevi et al. 2015).

In this study, most of the traits exhibited high broadsense heritability. High heritability coupled with high genetic advance showed by grain total per panicle and grain yield per hill, indicating the role of the additive gene expression of these traits.

Table 3. Variances, Coefficient of variation (\%), broad-sense heritability $\left(\mathrm{h}^{2} \mathrm{bs}\right)$, genetic advance, and genetic advance as percent of the mean for 12 traits of eight red rice lines evaluated

\begin{tabular}{|c|c|c|c|c|c|c|c|c|}
\hline \multirow{2}{*}{ Traits } & \multirow{2}{*}{$\bar{x}$} & \multicolumn{2}{|c|}{ Variance } & \multicolumn{2}{|c|}{ Coefficient of variance $(\%)$} & \multirow{2}{*}{ h2bs (\%) } & \multirow{2}{*}{ GA } & \multirow{2}{*}{ GAM } \\
\hline & & $\sigma_{g}^{2}$ & $\sigma_{p}^{2}$ & GCV & PCV & & & \\
\hline $\mathrm{PH}$ & 45.73 & 33.69 & 36.73 & 12.69 & 13.25 & 91.72 & 11.45 & 25.03 \\
\hline LA & 12.74 & 7.51 & 8.01 & 21.52 & 22.22 & 93.76 & 5.47 & 42.93 \\
\hline FLA & 12.41 & 4.83 & 5.11 & 17.70 & 18.21 & 94.52 & 4.40 & 35.46 \\
\hline FLW & 24.45 & 30.48 & 32.83 & 22.58 & 23.44 & 92.84 & 10.96 & 44.83 \\
\hline PL & 23.96 & 6.34 & 6.50 & 10.51 & 10.64 & 97.54 & 5.12 & 21.37 \\
\hline FG/P & 77.31 & 72.50 & 75.93 & 11.01 & 11.27 & 95.48 & 17.14 & 22.17 \\
\hline GT/P & 137.59 & 2169.51 & 2198.41 & 33.85 & 34.08 & 98.68 & 95.31 & 69.27 \\
\hline GW/P & 2.67 & 0.49 & 0.51 & 26.26 & 26.70 & 96.08 & 1.41 & 52.81 \\
\hline TGW & 28.02 & 7.25 & 7.72 & 9.61 & 9.91 & 93.91 & 5.38 & 19.20 \\
\hline DTF & 67.78 & 1.78 & 1.90 & 53.82 & 55.68 & 93.68 & 2.66 & 3.92 \\
\hline DTM & 100.07 & 82.51 & 82.67 & 13.40 & 13.41 & 99.81 & 18.69 & 18.68 \\
\hline GY & 26.71 & 119.74 & 112.15 & 10.47 & 10.58 & 97.85 & 21.35 & 79.93 \\
\hline
\end{tabular}

Note: Phenotypic variance $\left(\sigma^{2} \mathrm{~g}\right)$, genotypic variance $\left(\sigma^{2} \mathrm{p}\right)$, genotypic coefficient of variation (GCV), phenotypic coefficient of variation $(\mathrm{PCV})$, broad-sense heritability $\left(\mathrm{h}^{2} \mathrm{bs}\right)$, genetic advance (GA), and genetic advance as percent of mean (GAM). PH: Plant height, LA: Leaf area, FLA: Flag leaf angle, FLW: Flag leaf area, PL: Panicle length, FG/P: Filled grain percentage, GT/P: Grain total per panicle, GW/P: Grain weight per panicle, TGW: Thousand-grain weight, DTF: Days to 50\% flowering, DTM: Days to maturity, GY: Grain yield per hill 
Table 4. Coefficient correlation for yield-related traits of eight promising lines of red rice evaluated

\begin{tabular}{|c|c|c|c|c|c|c|c|c|c|c|c|c|}
\hline Traits & $\mathbf{P H}$ & LA & FLA & FLW & PL & FG/P & GT/P & GW/P & TGW & DTF & DTM & GY \\
\hline $\mathrm{PH}$ & 1 & $0.70 * *$ & 0.33 & $0.53 * *$ & $0.52 * *$ & -0.36 & $0.67 * *$ & $0.43^{*}$ & -0.03 & 0.36 & $0.45^{*}$ & -0.12 \\
\hline LA & & 1 & $0.58 * *$ & $0.43^{*}$ & $0.57 * *$ & $-0.48 *$ & $0.70 * *$ & $0.63 * *$ & 0.13 & $0.61 * *$ & $0.53 * *$ & -0.33 \\
\hline FLA & & & 1 & $0.46^{*}$ & $0.40^{*}$ & -0.11 & $0.55 * *$ & $0.57 * *$ & 0.23 & $0.48^{*}$ & 0.37 & -0.34 \\
\hline FLW & & & & 1 & 0.37 & -0.04 & $0.55 * *$ & $0.50 * *$ & 0.19 & 0.05 & 0.10 & -0.02 \\
\hline PL & & & & & 1 & $-0.51 * *$ & $0.88 * *$ & $0.82 * *$ & 0.34 & $0.80 * *$ & $0.89 * *$ & $0.63 * *$ \\
\hline $\mathrm{FG} / \mathrm{P}$ & & & & & & 1 & $-0.41^{*}$ & -0.29 & -0.13 & $-0.62 * *$ & $-0.60 * *$ & $0.53 * *$ \\
\hline GT/P & & & & & & & 1 & $0.89 * *$ & 0.23 & $0.71 * *$ & $0.82 * *$ & -0.28 \\
\hline GW/P & & & & & & & & 1 & $0.41 *$ & $0.71 * *$ & $0.73 * *$ & $0.54 * *$ \\
\hline TGW & & & & & & & & & 1 & 0.34 & 0.25 & $0.52 * *$ \\
\hline DTF & & & & & & & & & & 1 & $0.94^{* *}$ & $-0.61 * *$ \\
\hline DTM & & & & & & & & & & & 1 & $-0.48^{*}$ \\
\hline GY & & & & & & & & & & & & 1 \\
\hline
\end{tabular}

Note: *Significance at the 5\% level, and **Significance at the 1\% level. PH: Plant height, LA: Leaf area, FLA: Flag leaf angle, FLW: Flag leaf area, PL: Panicle length, FG/P: Filled grain percentage, GT/P: Grain total per panicle, GW/P: Grain weight per panicle, TGW: Thousand-grain weight, DTF: Days to 50\% flowering, DTM: Days to maturity, GY: Grain yield per hill.

The effectiveness of selection in any crop depends on the nature and magnitude of phenotypic and genotypic variability present in different agronomic traits of the population (Bahadur et al. 2016). Genetic parameters such as genotypic coefficient of variation, heritability, and genetic advance are needed to improve crops. The knowledge of genetic parameters for desirable traits is a prerequisite for the success of crop improvement programs (Roychowdhury et al. 2012).

Genetic diversity is the basis for the survival of plants in nature and crop improvement (Bhandari et al. 2017). A high genotypic coefficient of variation indicates the availability of high genetic variation (Ene et al. 2016; Gebregergs and Mekbib, 2020). On the other hand, a low genotypic coefficient of variation also indicates the narrow genetic variability, and the selection is not effective for a particular character. The PCV and GCV are not only useful for comparing the relative amounts of phenotypic and genotypic variations among different traits but are very useful for estimating the scope of improvement through selection (Bello et al. 2012).

The heritability information, genetic advance of yield attributing traits, and their association will help plant breeders identify the characters that are effective for selection (Bello et al. 2012; Dabalo et al. 2020). Heritability is an essential factor in determining the response of selection and breeding programs. Its estimations are important aspect of the inheritance of quantitative traits as they indicate the genetic gains that may be gained through selection (Schmidt et al. 2019). Heritability estimates and genetic advances are usually more helpful in predicting the gain under selection than heritability estimates alone (Cooper et al. 2021).

\section{Correlation coefficient analysis}

Pearson correlation analysis among traits, yield, and its related traits are shown in Table 4 . The results revealed that panicle length, filled grain percentage, grain weight per panicle, and thousand-grain weight were highly positive significant correlations present with yield. These results agreed with the previous research result (Sadimantara et al. 2018).
Correlation coefficient analysis measures the mutual relationship between various plant characters and determines the component characters on which selection can be based for genetic improvement in yield. Correlation among traits is generally due to the presence of linkage and pleiotropic effect of different genes (Deep et al. 2017). Correlation coefficient analysis is also widely used to measure the degree and direction of relationships between various traits, including grain yield (Tiwari et al. 2019; Rachana et al. 2021).

Panicle length showed a significant positive correlation with plant height, leaf area, grain weight per panicle, grain total per panicle, filled grains per panicle, days to $50 \%$ flowering, days to maturity, and grain yield per hill. Earlier researchers, Patel et al. (2014), Ketan and Sarkar (2014), Ramanjaneyulu et al. (2014), Liu et al. (2016), Shamim et al. (2017), Onyia et al. (2017), and Pratap et al. (2018) reported similar results. The grain weight per panicle and panicle length is considered an essential component for achieving high yield because it showed a significant and positive association with grain total per panicle, 1000 grain weight, days to $50 \%$ flowering, days to maturity, and grain yield per hill. Similar results were also reported by Gopikannan and Ganesh (2013), Thippani et al. (2017), and Venkanna et al. (2014). The panicle length and grain weight per panicle trait would be effective in the direct selection process. On the other hand, days to $50 \%$ flowering showed a strong negative association with yield, so this trait must be excluded from direct selection. Similarly, plant height and leaf area showed a nonsignificant negative correlation with yield and met with the findings of Rawte and Saxena (2017).

The difference of 1000 grains weight of each treatment is genetically derived from each rice lines trait. The studies of Aghamolki et al. (2015) found that the grain yield had a positive and significant correlation with the number of grains per panicle, the number of filled grains per panicle, and 1000-grain weight. However, a negative and significant correlation of grain yield per hill was observed with days to maturity, days to $50 \%$ flowering followed by leaf area, and flag leaf angle. This finding was in confirmation with the results of Lingaiah et al. (2014), 
Sohgaura et al. (2014), Onyia et al. (2017), and Hosagoudar and Kovi (2018).

In conclusion, The character with high PCV, GCV, and heritability are days to $50 \%$ flowering, grain total per panicle, and grain weight per panicle. High heritability coupled with high genetic advance was observed for grain total per panicle and grain yield per hill. A high percentage of the genetic advance of the mean value was found in the characters GTP, GWP, and GY. The panicle length, the percentage of filled grains, grain weight per panicle, and thousand-grain weight were found a significantly positive correlation with the yield of red rice promising lines. Based on the value of heritability, genetic variability, and genetic advance, the character used as selection criteria in this study are grains total per panicle and grain weight per panicle. Both GTP and GWP are considered important yield-related traits and could be used for selection to improve the genetic potential of rice yield.

\section{ACKNOWLEDGEMENTS}

The authors thank the Directorate General of Research of the Ministry of Research, Technology, and Higher Education of the Republic of Indonesia for funding this study.

\section{REFERENCES}

Adhikari BN, Joshi BP, Shrestha J, Bhatta NR. 2018. Genetic variability, heritability, genetic advance and correlation among yield and yield components of rice (Oriza sativa L.). J Agric Nat Resour 1 (1): 149 160. DOI: 10.3126/janr.v1i1.22230.

Aghamolki MTK, Yusop MK, Jaafar HZ, Kharidah S, Musa MH, Zandi P. 2015. Preliminary analysis of growth and yield parameters in rice cultivars when exposed to different transplanting dates. Electron $\mathrm{J}$ Biol 11: 147-153.

Ajmera S, Kumar SS, Ravindrababu V. 2017. Evaluation of genetic variability, heritability and genetic advance for yield and yield components in rice genotypes. Intl J Curr Microbiol Appl Sci 6 (10): 1657-1664. DOI: 10.20546/ijcmas.2017.610.200.

Akter A, Hasan M, Latif M, Kulsum M, Biswas P, Rahman M, Majumder R, Lipi L, Quddus M, Akter F, Ara A. 2020. Genetic variability, heritability, correlation and path coefficient studies for yield and yield components of some promising rice hybrids. Bangladesh Rice J 23 (2): 27-34. DOI: 10.3329/brj.v23i2.48245.

Akter A, Jamil HM, Umma KM, Islam MR, Hossain K, Mamunur RM. 2014. AMMI biplot analysis for stability of grain yield in hybrid rice (Oryza sativa L.). J Rice Res 2 (2): 126. DOI: 10.4172/jrr.1000126.

Ansari A, Julfiquar AW, Rasul MG, Hasan MJ, Rahman MM. 2010 Genetic parameter, correlation and path analysis for yield and yield related traits in some maintainer lines of hybrid rice (Oryza sativa $\mathrm{L})$. Eco-friendly Agric J 3 (2): 89-95.

Bahadur V, Yeshudas V, Meena OP. 2016. Nature and magnitude of genetic variability and diversity analysis of ndian turmeric accessions using agro-morphological descriptors. Can J Plant Sci 96:3 71-381. DOI: $10.1139 /$ cjps-2015-0228.

Bailey-Serres J, Parker JE, Ainsworth EA, Oldroyd GED, Schroeder JI. 2019. Genetic strategies for improving crop yields. Nature 575 (7781): 109-118. DOI: 10.1038/s41586-019-1679-0.

Bello OB, Ige SA, Azeez MA, Afolabi MS, Abdulmaliq SY, Mahamood J. 2012. Heritability and genetic advance for grain yield and its component characters in maize (Zea mays L.). Intl J Plant Res 2 (5) 138-145. DOI: 10.5923/j.plant.20120205.01.

Bhandari HR, Bhanu AN, Srivastava K, Singh MN, Shreya HA. 2017. Assessment of genetic diversity in crop plants-an overview. Adv Plants Agric Res 7 (3): 255. DOI: 10.15406/apar.2017.07.00255.
Burton GW. 1952. Quantitative inheritance in grasses. Pro VI Int Grassl Cong 1952: 277-283.

Choudhary P, Mishra DK, Koutu GK, Pachori A, Singh SK. 2018. Interrelationship of yield and quality attributing traits in JNPT Lines of rice. Int J Bio-Resource Stress Manag 9 (3): 330-340. DOI: 10.23910/IJBSM/2018.9.3.3C0934.

Cooper M, Powell O, Voss-Fels KP, Messina CD, Gho C, Podlich DW, Technow F, Chapman SC, Beveridge CA, Ortiz-Barrientos D. 2021. Modelling selection response in plant-breeding programs using crop models as mechanistic gene-to-phenotype (CGM-G2P) multi-trait link functions. In Silico Plants 3 (1): 1-21. DOI: 10.1093/insilicoplants/diaa016.

Dabalo DY, Singh BCS, Weyessa B. 2020. Genetic variability and association of characters in linseed (Linum usitatissimum L.) plant grown in central Ethiopia region. Saudi J Biol Sci 27: 2192-2206. DOI: $10.1016 /$ j.sjbs.2020.06.043.

Deep R, Shoumik S, Bapsila L, Sakshi S, Singh PK. 2017. Genetic variability study for yield and yield components in rice (Oryza sativa L.). Int J Agric Environ Biotechnol 10: 171-176. DOI: 10.5958/2230732X.2017.00020.1.

Devi KR, Chandra BS, Lingaiah N, Hari Y, Venkanna V. 2017. Analysis of variability, correlation and path coefficient studies for yield and quality traits in rice (Oryza sativa L.). Agric Sci Dig Res J 37 (1): 1-9. DOI: 10.18805/asd.v0iOF.7328.

Ene CO, Ogbonna PE, Agbo CU, Chukwudi UP. 2016. Studies of phenotypic and genotypic variation in sixteen cucumber genotypes. Chil J Agric Res 76: 307-313. DOI: 10.4067/S071858392016000300007.

Falconer DS. 1996. Introduction to quantitative genetics. Pearson Education, India.

Gautam A, Suresh J, Madhav MS. 2016. Study of genetic variability in genotypes of rice (Oryza sativa L.). Res J Agric Sci 7 (1): 235-236.

Gebregergs G, Mekbib F. 2020. Estimation of genetic variability, heritability, and genetic advance in advanced lines for grain yield and yield components of sorghum [Sorghum bicolor (1.) Moench] at Humera, Western Tigray, Ethiopia. Cogent Food Agric 6 (1): 1764181. DOI: 10.1080/23311932.2020.1764181.

Gopikannan M, Ganesh SK. 2013. Uncertainty in seasonal climate projection over Tamil Nadu for 21st century. Afr J Agric Res 8 (32): 4334-4344. DOI: 10.5897/AJAR2013.7456.

Goufo P, Trindade H. 2014. Rice antioxidants: Phenolic acids, flavonoids, anthocyanins, proanthocyanidins, tocopherols, tocotrienols, $\gamma$-oryzanol, and phytic acid. Food Sci Nutr 2: 75-104. DOI: 10.1002/fsn3.86.

Govindaraj M, Vetriventhan M, Srinivasan M. 2015. Importance of genetic diversity assessment in crop plants and its recent advances: An overview of its analytical perspectives. Genet Res Intl 2015: 431487. DOI: $10.1155 / 2015 / 431487$.

Griffiths JF, Griffiths AJF, Wessler SR, Lewontin RC, Gelbart WM, Suzuki DT, Miller JH. 2005. An Introduction to Genetic Analysis. Macmillan, New York.

Hosagoudar GN, Kovi BS. 2018. Evaluation of advanced varietal rice genotypes for leaf blast reaction, genotypic performance and correlation studies. Intl J Curr Microbiol Appl Sci 7 (4): 75-81. DOI: 10.20546/ijcmas.2018.704.009

Hossain S, Haque MD M, Rahman J. 2016. Genetic variability, correlation and path coefficient analysis of morphological traits in some extinct local aman rice (Oryza sativa L). Rice Res 4 (1): 4-9. DOI: 10.4172/2375-4338.1000158.

Huda M, Ferdausi A, Hassan L, Hossain M. 2018. Evaluation of the genetic variability and genetic advance for salt tolerance in rice genotypes. Progress Agric 28 (4): 262-270. DOI: 10.3329/pa.v28i4.36365.

Hyoda T, Homma K, Shiraiwa T, Katsura K, Horie T. 2015. Adaptability of high-yielding rice cultivars in relation to biomass productivity under moderately water stressed upland conditions. Agric Sci 6 (3): 352. DOI: 10.4236/as.2015.63036.

Islam M, Raffi S, Hossain M, Hasan A. 2015. Analysis of genetic variability, heritability and genetic advance for yield and yield associated traits in some promising advanced lines of rice. Progress Agric 26 (1): 26-31. DOI: 10.3329/pa.v26i1.24511.

Johnson HW, Robinson HF, Comstock RE. 1955. Estimates of genetic and environmental variability in soybeans 1. Agron J 47 (7): 314-318. DOI: 10.2134/agronj1955.00021962004700070009x.

Kadidaa B, Sadimantara GR, Suaib, Safuan LO, Muhidin. 2017. Genetic diversity of local upland rice (Oryza sativa L.) genotypes based on 
agronomic traits and yield potential in North Buton, Indonesia. Asian J Crop Sci 9 (4): 109-117. DOI: 10.3923/ajcs.2017.109.117.

Kaiser N, Douches D, Dhingra A, Glenn KC, Herzig PR, Stowe EC, Swarup S. 2020. The role of conventional plant breeding in ensuring safe levels of naturally occurring toxins in food crops. Trends Food Sci Technol 100: 51-66. DOI: 10.1016/j.tifs.2020.03.042.

Keerthana K, Chitra S, Subramanian A, Nithila S, Elangovan M. 2019. Studies on genetic variability in finger millet [Eleusine coracana $(\mathrm{L}$. Gaertn] genotypes under sodic conditions. Electr J Plant Breed 10 (2): 566-569. DOI: 10.5958/0975-928X.2019.00071.1.

Ketan R, Sarkar G. 2014. Studies on variability, heritability, genetic advance and path analysis in some indigenous Aman rice (Oryza sativa L.). J Crop Weed 10 (2): 308-315.

Khan ASMMR, Eyasmin R, Rashid MH, Ishtiaque S, Chaki AK. 2016. Variability, heritability, character association, path analysis and morphological diversity in snake gourd. Agric Nat Resour 50 (6): 483-489. DOI: 10.1016/j.anres.2016.07.005.

Khan MH, Dar ZA, Dar SA. 2015. Breeding strategies for improving rice yield-a review. Agric Sci 6 (5): 467. DOI: 10.4236/as.2015.65046.

Kumar P, Arya VK, Kumar P, Kumar L, Singh J. 2017. Study on genetic variability, heritability and genetic advance for seed yield and component traits in Rice. J AgriSearch 4 (3): 173-178. DOI: 10.21921/jas.v4i03.9017.

Lenaerts B, de Mey Y, Demont M. 2018. Global impact of accelerated plant breeding: Evidence from a meta-analysis on rice breeding. PLoS One 13 (6): e0199016. DOI: 10.1371/journal.pone.0199016.

Li R, Li M, Ashraf U, Liu S, Zhang J. 2019. Exploring the relationships between yield and yield-related traits for rice varieties released in China from 1978 to 2017. Front Plant Sci 10: 543. DOI 10.3389/fpls.2019.00543

Lingaiah N, Venkanna V, Cheralu C, Chandra BS. 2014. Variability, heritability and genetic advance for yield and yield attributing traits in mid early genotypes of rice (Oryza aativa L.). Ijarset 1 (4): 179-180.

Liu E, Liu Y, Wu G, Zeng S, Tran Thi TG, Liang L, Liang Y, Dong Z, She D, Wang H. 2016. Identification of a candidate gene for panicle length in rice (Oryza sativa L.) via association and linkage analysis. Front Plant Sci 7: 596. DOI: 10.3389/fpls.2016.00596.

Manzanilla DO, Paris TR, Vergara GV, Ismail AM, Pandey S, Labios RV, Tatlonghari GT, Acda RD, Chi TTN, Duoangsila K. 2011 Submergence risks and farmers' preferences: Implications for breeding Sub1 rice in Southeast Asia. Agric Syst 104: 335-347. DOI: 10.1016/j.agsy.2010.12.005.

Muhidin, Jusoff K, Syam'un E, Musa Y, Kaimuddin, Meisanti, Sadimantara GR, Rianda L. 2013. The development of upland red rice under shade trees. World Appl Sci J 24: 23-30.

Muhidin, Leomo S, Alam S, Wijayanto T. 2016. Comparative studies on different agroecosystem base on soil physicochemical properties to development of sago palm on dryland. Intl J ChemTech Res 9: 511518.

Muhidin. Syam'un E, Kaimuddin, Musa Y, Sadimantara GR, Usman, Leomo S, Rakian TC. 2018. The effect of shade on chlorophyll and anthocyanin content of upland red rice. IOP Conf Ser Earth Environ Sci 122: 012030. DOI: 10.1088/1755-1315/122/1/012030.

Nirmaladevi G, Padmavathi G, Kota S, Babu VR. 2015. Genetic variability, heritability and correlation coefficients of grain quality characters in rice (Oryza sativa L.). Sabrao J Breed Genet 47 (4): 424 433

Oladosu Y, Rafii MY, Abdullah N, Abdul Malek M, Rahim HA, Hussin G, Abdul Latif M, Kareem I. 2014. Genetic variability and selection criteria in rice mutant lines as revealed by quantitative traits. Sci World J 2014: 190531. DOI: 10.1155/2014/190531.

Onyia VN, Okechukwu EC, Atugwu AI, Akpan NM. 2017. Genetic variability studies on twelve genotypes of rice (Oryza sativa L.) for growth and yield performance in south eastern Nigeria. Not Sci Biol 9 (1): 110-115. DOI: $10.15835 / \mathrm{nsb} 919980$.

Osei MK, Asante MD, Agyeman A, Adebayo MA, Adu-Dapaah H. 2014 Plant breeding: A tool for achieving food sufficiency. In: Sustainable Horticultural Systems. Springer, New York.

Panuju DR, Mizuno K, Trisasongko BH. 2013. The dynamics of rice production in Indonesia 1961-2009. J Saudi Soc Agric Sci 12: 27-37. DOI: 10.1016/j.jssas.2012.05.002.

Patel JR, Saiyad MR, Prajapati KN, Patel RA, Bhavani RT. 2014. Genetic variability and character association studies in rainfed upland rice (Oryza sativa L.). Electr J Plant Breed 5 (3): 531-537.

Pratap A, Bisen P, Loitongbam B, Sandhya, Singh PK. 2018. Assessment of genetic variability for yield and yield components in rice (Oryza sativa L.) germplasms. Intl J Bio-resource Stress Manag 9 (1): 87-92. DOI: 10.23910/ijbsm/2018.9.1.3c0818.

Pratap A, Das A, Kumar S, Gupta S. 2020. Current perspectives on introgression breeding in food legumes. Front Plant Sci 11: 589189. DOI: $10.3389 /$ fpls.2020.589189.

Priyanka K, Jaiswal HK. 2017. Genetic analysis of yield and yield contributing traits in boro rice (Oryza sativa L.) over environments. Bangladesh J Agric Res 42: 457-466. DOI: 10.3329/bjar.v42i3.34504.

Qaim M. 2020. Role of new plant breeding technologies for food security and sustainable agricultural development. Appl Econ Perspect Policy 42 (2): 129-150. DOI: 10.1002/aepp.13044.

Ramanjaneyulu AV, Shankar VG, Neelima TL, Shashibhusahn D. 2014. Genetic analysis of rice (Oryza sativa L.) genotypes under aerobic conditions on alfisols. Sabrao J Breed Genet 46 (1): 99-111.

Rachana P, Binju M, Suprava A, Bigyan KC, Rishav P, Rashmi R, Bishnu B, Pritika N, Kushal B, Ram PM. 2021. Correlation and path coefficient analysis of yield in wheat: A Review. Russ J Agric SocioEconomic Sci 5: 121. DOI: 10.18551/rjoas.2021-05.14.

Rashmi D, Saha S, Loitongbam B, Singh S, Singh PK. 2017. Genetic variability study for yield and yield components in rice (Oryza sativa L.). Int J Agric Environ Biotechnol 10 (2): 171. DOI: 10.5958/2230732X.2017.00020.1

Ravichanthiran K, Ma ZF, Zhang H, Cao Y, Wang CW, Muhammad S, Aglago EK, Zhang Y, Jin Y, Pan B. 2018. Phytochemical profile of brown rice and its nutrigenomic implications. Antioxidants 7: 71 . DOI: 10.3390/antiox7060071

Ravishanker SK, Chatterjee A, Baranwal DK, Solankey SS. 2013. Genetic variability for yield and quality traits in ginger (Zingiber officinale Roscoe). The Bioscan 8 (4): 1383-1386.

Rawte S, Saxena RR. 2017. Correlation and path coefficient analysis of quality traits in selected rice (Oryza sativa L.) germplasm accessions. Int J Chem Stud 5 (5): 547-551.

Reddy MP, Reddy BN, Arsul BT, Maheshwari JJ. 2013. Genetic variability, heritability and genetic advance of growth and yield components of linseed (Linum usitatissimum L.). Intl J Curr Microbiol Appl Sci 2 (9): 231-237.

Robinson HF, Comstock RE, Harvey PH. 1949. Estimates of heritability and the degree of dominance in corn 1. Agron J 41 (8): 353-359. DOI: 10.2134/agronj1949.00021962004100080005x.

Roy SC, Shil P. 2020. Assessment of genetic heritability in rice breeding lines based on morphological traits and caryopsis ultrastructure. Sci Rep 10 (1): 1-17. DOI: 10.1038/s41598-020-63976-8.

Roychowdhury R, Datta S, Gupta P, Tah J. 2012. Analysis of genetic parameters on mutant populations of mungbean (Vigna radiata L.) after ethyl methane sulphonate treatment. Not Sci Biol 4: 137-143. DOI: $10.15835 / \mathrm{nsb} 417327$.

Sadimantara GR, Cahyono E. 2014. Genetic Analysis on some agromorphological characters of hybrid progenies from cultivated paddy rice and local upland rice. Adv Stud Biol 6 (1): 7-18. DOI: 10.12988/asb.2014.423

Sadimantara GR, Muhidin, Sri Suliartini NW, Nuraida W, Sadimantara MS, Leomo S, Ginting S. 2018. Agronomic and yield characteristics of new superior lines of amphibious rice derived from paddy rice and local upland rice crossbreeding in konawe of Indonesia. Biosci Res 15 (2): 893-899.

Sadimantara GR, Alawyah T, Suliartini NWS, Febrianti E, Muhidin. 2019. Growth performance of two superior line of local upland rice (Oryza sativa L.) from SE Sulawesi on the low light intensity. IOP Conf Ser Earth Environ Sci 260: 12145. DOI: 10.1088/1755$1315 / 260 / 1 / 012145$

Saha SR, Hassan L, Haque MA, Islam MM, Rasel M. 2019. Genetic variability, heritability, correlation and path analyses of yield components in traditional rice (Oryza sativa L.) landraces. J Bangladesh Agric Univ 17 (1): 26-32. DOI: 10.3329/jbau.v17i1.40659.

Schmidt P, Hartung J, Bennewitz J, Piepho HP. 2019. Heritability in plant breeding on a genotype-difference basis. Genetics 212: 991-1008. DOI: $10.1534 /$ genetics.119.302134.

Senapati AK, Prajapati P, Singh A. 2013. Genetic variability and heritability studies in Gerbera jamesonii Bolus. BIOINFOLET - A Q J Life Sci 10 (4c): 1531-1533. DOI: 10.5897/AJAR2013.8038.

Shamim MZ, Sharma VK, Manzar H, Bhushan S. 2017. Grain yield components analysis in locally adapted rice varieties. Int $\mathrm{J}$ Agric Environ Biotechnol 10 (4): 435-442. DOI: 10.5958/2230 732X.2017.00054.7 
Shrivastava A, Koutu GK, Mishra DK, Singh SK. 2015. Characterization of JNPT lines of rice (Oryza sativa L.). Plant Arch 15 (1): 397-403.

da Silva Dias JC. 2015. Plant breeding for harmony between modern agriculture production and the environment. Agric Sci 6 (1): 87. DOI: 10.5772/60080.

Singh SK, Singh CM, Lal GM. 2011. Assessment of genetic variability for yield and its component characters in rice (Oryza sativa L.). Res Plant Biol 1 (4): 73-76.

Sivamaruthi BS, Kesika P, Chaiyasut C. 2018. Anthocyanins in Thai rice varieties: Distribution and pharmacological significance. Int Food Res J 25: 2024-2032

Sivasubramanian S, Madhavamenon P. 1973. Genotypic and phenotypic variability in rice. Madras Agric J 12: 15-16.

Sohgaura N, Mishra DK, Koutu GK, Singh SK, Kumar V. 2014. Genetic evaluation of inter sub-specific derived RILs population for yield and quality attributes in rice. Trends Biosci 7 (18): 2631-2638.

Sravan T, Rangare NR, Eswara RG, Ashok RP. 2014. Study of heritability, genetic advance and variability for yield contributing characters in upland rice germplasm (Oryza sativa $\mathrm{L}$.). Trends Biosci 7 (12): 1291-1296.

Srujana G, Suresh BG, Lavanya GR, Ram BJ, Sumanth V. 2017. Studies on genetic variability, heritability and genetic advance for yield and quality components in rice (Oryza sativa L.). J Pharmacogn Phytochem 6 (4): 564-566.

Suliartini NWS, Wijayanto T, Madiki A, Boer B, Muhidin, Tufaila M. 2018. Yield potential improvement of upland red rice using gamma irradiation on local upland rice from Southeast Sulawesi Indonesia. Biosci Res 15: 1673-1678.

Sutariati GAK, Khaeruni A, Pasolon YB. 2016. The effect of seed bioinvigoration using indigenous rhizobacteria to improve viability and vigor of upland rice (Oryza sativa L.) seeds. Intl J PharmTech Res 9: 565-573.

Sutariati GAK, Arif N, Muhidin, Rakian TC, Mudi L, Nuralam. 2017. Persistency and seed breaking dormancy on local upland rice of
Southeast Sulawesi, Indonesia. Pak J Biol Sci 20 (11): 563-570. DOI: 10.3923/pjbs.2017.563.570.

Sutariati GAK, Muhidin, Rakian TC, Afa LO, Widanta IM, Mudi L, Sadimantara GR, Leomo S. 2018. The effect of integrated application of pre-plant seed bio-invigoration, organic and inorganic fertilizer on the growth and yield of local upland rice. Biosci Res 15: 160-165.

Takai T, Lumanglas P, Simon EV, Arai-Sanoh Y, Asai H, Kobayashi N. 2019. Identifying key traits in high-yielding rice cultivars for adaptability to both temperate and tropical environments. Crop J 7 (5): 685-693. DOI: 10.1016/j.cj.2019.06.004.

Terfa GN, Gurmu GN. 2020. Genetic variability, heritability and genetic advance in linseed (Linum usitatissimum L.) genotypes for seed yield and other agronomic traits. Oil Crop Sci 5 (3): 156-160. DOI: 10.1016/j.ocsci.2020.08.002.

Thanuja B, Parimalavalli R. 2018. Role of black rice in health and diseases. Intl J Heal Sci Res 8: 241-248.

Thippani S, Kumar SS, Senguttuvel P, Madhav MS. 2017. Correlation analysis for yield and yield components in rice (Oryza sativa L.). Intl J Pure App Biosci 5 (4): 1412-1415. DOI: 10.18782/2320-7051.5658.

Tiwari DN, Tripathi SR, Tripathi MP, Khatri N, Bastola BR. 2019. Genetic variability and correlation coefficients of major traits in early maturing rice under rainfed lowland environments of Nepal. Adv Agric 2019: 5975901. DOI: 10.1155/2019/5975901.

Venkanna V, Rao MVB, Raju CHS, Rao VT, Lingaiah N. 2014. Association analysis of $\mathrm{F} 2$ Generation in rice (Oryza sativa. L.). Int $\mathrm{J}$ Pure App Biosci 2 (2): 198-203.

Xu Y, Li P, Zou C, Lu Y, Xie C, Zhang X, Prasanna BM, Olsen MS. 2017. Enhancing genetic gain in the era of molecular breeding. J Exp Bot 68 (11): 2641-2666. DOI: 10.1093/jxb/erx135.

Yan AO, Yong XU, Xiao-fen C, An W, Fei T, Li-qun S, Qiao-quan L. 2016. A genetic diversity assessment of starch quality traits in rice landraces from the Taihu basin, China. J Integr Agric 15 (3): 493-501. DOI: 10.1016/S2095-3119(15)61050-4. 